\title{
Clinical Trial on the Influence of the Consumption of Dyes during Supervised and Domestic Tooth Bleaching
}

\section{Natália Maria Velozo dos Santos ${ }^{1}$, Fernanda Buccolo Losada ${ }^{1}$ and Renata Pedrosa Guimarães ${ }^{2 *}$}

${ }^{1}$ Graduation in Dentistry, Universidade Federal de Pernambuco, Brazil

${ }^{2}$ Adjunct Professor, Universidade Federal de Pernambuco, Brazil

*Corresponding author: Renata Pedrosa Guimarães, Adjunct Professor, Universidade Federal de Pernambuco, Av Ministro Marcos Freire, 4443/303, Casa Caiada, Olinda- PE, CEP: 53040-010, Brazil, Tel: 81-987140518

\begin{abstract}
Objective: The influence of color drinks consumption during supervised and domestic bleaching treatment was evaluated through a clinical trial.

Materials and methods: Fifty patients were randomly assigned to five groups ( $n=10)$ : PC: Supervised bleaching with Carbamide Peroxide 10\% (Whiteness Perfect/FGM) with diet restriction; PC+: Supervised bleaching with $10 \%$ Carbamide Peroxide (Whiteness Perfect/FGM) with use of dye solution; GC: Daily brushing with conventional dentifrice (Triple Action/Colgate); LW-: Daily brushing with Luminous White Advanced/Colgate with restriction diet; LW+: Daily brushing with Luminous White Advanced/Colgate toothpaste with use of dye solution. At the end and 15 days after treatment, readings of chromatic changes were performed using a spectrophotometer.
\end{abstract}

Results: Comparison between mean values of $\Delta \mathrm{E}$ showed differences between PC- $(\Delta E=4.28)$ and $P C+(\Delta E=4.42)$ when compared to $\mathrm{GC}(\Delta \mathrm{E}=0.97)$, LW- $(\Delta \mathrm{E}=0.43)$ and $\mathrm{LW}+(\Delta \mathrm{E}=0.30)$. There were no differences between PCand $\mathrm{PC}+$ nor between $\mathrm{LW}$ - and LW+.

Conclusions: There was no difference between the groups for the reports of sensitivity $(p>0.05)$. Contact with dye did not influence the results of supervised and domestic bleaching. Home bleaching with whitening toothpaste was not effective.

\section{Clinical Significance}

It is possible to perform dental whitening without restricting food.

\section{Indexers}

Tooth whitening, Diet, Food coloring agents, Peroxides, Clinical analysis

\section{Introduction}

The demand for a harmonious smile and with whiter teeth is currently one of the main reasons that lead the patient to look for a dental treatment, since the appearance of the smile has great relevance on the psychological and interpersonal aspects $[1,2]$. The chromatic change of teeth happens due to extrinsic and intrinsic factors. Changes in intrinsic origin may happen due to systemic diseases, changes in tooth formation, dental trauma, pulpal necrosis, drug use, fluorosis and by the dental aging process itself. Among the extrinsic factors are: Smoking, medications such as Chlorhexidine, accumulation of biofilms, and especially the ingestion of foods and beverages that contain dyes such as cola, coffee, red wine and black tea [3].

Bleaching has become the aesthetic treatment most commonly performed in adults and its popularity can be easily explained by the fact that, when properly performed, it is the simplest, least invasive and less costly treatment to restore color harmony in vitalized and devitalized teeth or eliminate any stains [1]. The chemical process of tooth whitening consists of an ox reduction reaction, in which the amount of pigments removed are proportional to the time of exposure of the enamel to the bleaching agent, as well as its concentration, according to the pre-established limits for the maintenance of the hygiene of dental and periodontal structures [4].

The bleaching treatment can be performed by different methods known as supervised whitening, office

Citation: dos Santos NMV, Losada FB, Guimarães RP (2019) Clinical Trial on the Influence of the Consumption of Dyes during Supervised and Domestic Tooth Bleaching. Int J Oral Dent Health 5:101. doi.org/10.23937/2469-5734/1510101

Accepted: October 19, 2019: Published: October 21, 2019

Copyright: (c) 2019 dos Santos NMV, et al. This is an open-access article distributed under the terms of the Creative Commons Attribution License, which permits unrestricted use, distribution, and reproduction in any medium, provided the original author and source are credited. 
whitening and also the association of these techniques. The supervised technique uses carbamide peroxide in concentrations of 10 to $22 \%$ or hydrogen peroxide in concentrations of 2 to $7 \%$. Through a simple protocol, the patient himself/herself performs the treatment by using individual trays filled with the low concentration bleaching gel, for a period of time recommended by the Dental Surgeon [5]. Due to the safety of use and available scientific evidence, supervised whitening with $10 \%$ carbamide peroxide is the gold standard among whitening techniques [6].

There is a very large appeal currently by the media that involves and encourages the use of dentifrices, which promises a tooth whitening only by daily brushing. These dentifrices, in their majority, present in their composition a great proportion of abrasive agents, which remove more amount of biofilm, generating a false impression of whitening accompanied by a greater risk of damages to the enamel. It is also possible that the abrasive action generates excessive demage of these structures, increasing the porosity and predisposing the dental units to future stains $[7,8]$. Several types of toothpaste that offer a practical and fast whitening effect have been freely offered at drugstores and supermarkets shelves and they are acquired by patients, who normally make uninterrupted use of these cosmetics without professional guidance expecting to have their teeth effectively cleared [4].

One of the great drawbacks of the bleaching technique for patients has been the dietary restrictions with regard to dyestuffs [1]. It has been shown that coffee is capable of causing stains on the teeth because besides having a dark coloration, it has an acidic $\mathrm{pH}$. This would cause increased permeability and penetration into the tooth structure, causing color interference. Studies have indicated that teeth undergone to dental bleaching and exposed to coloring in the diet have, in fact, greater potential to have pigmentation. Leading to less longevity and stability of the whitening effect and inducing clinicians to impose dietary restrictions during these procedures. However, this is a controversial issue, other in vitro studies have concluded that ingestion of colored foods during tooth whitening did not interfere with the results obtained [9].

However, there is still no consensus in the literature about the correct and safe timing of the resumption of these foods, as well as the frequency of consumption that may impair the bleaching efficacy [5]. The discussion still persists on the importance of a dietary restriction during bleaching and this doubt assumes even greater relevance since the result of the supervised bleaching depends greatly on the way the patient performs the treatment. In domestic bleaching, with products that are easily accessible to patients, this influence is also important since, faced with an unsatisfactory re- sult, patients will tend to prolong the use of high abrasive bleaching dentifrices.

Thus, the present research tried to evaluate the influence of the consumption of food and color drinks during the supervised bleaching treatment with carbamide peroxide and domestic bleaching toothpaste through a clinical trial.

\section{Methodology}

(Approved by the Committee of Ethics in Research with Human beings of CCS CCAE: 67177817.4.0000.5208). The sample units were patients who looked for dental treatment in the Dentistry course clinics and who accepted to participate in the study, the variables being dependent: 1) Efficacy and speed of the whitening effect; 2) Presence of gingival alterations; 3 ) Incidence of tooth sensitivity; 4) Degree of patient satisfaction regarding treatment outcome; 5) Durability (maintenance) of the obtained bleaching effect.

Fifty patients from both sexes, over 18-years-old, were selected according to the following inclusion criteria: Presence of all anterior superior teeth natural, vitalized, naturally or physiologically darkened, without restorations involving the vestibular faces and with good oral health.

Patients who presented dental sensitivity, cervical lesions or fractures, smokers, pregnant women and infants, children and adolescents (up to 18-yearsold), previous history of cancerous lesions, caries and periodontal disease, prostheses and/or restorations involving the anterior teeth.

After anamnesis, physical examination and filling out a form of the clinical record, the patients received guidelines regarding oral hygiene, diet and aspects related to bleaching treatment, such as: Mechanism of action, adverse reactions, precautions during and after treatment.

Individuals who fitted in the inclusion criteria were randomly allocated into five groups $(n=10)$ : PC-: Supervised bleaching with 10\% Carbamide Peroxide (Whiteness Perfect/FGM-Joinville-SC-Brazil) with diet restriction; PC+: Supervised bleaching with $10 \%$ Carbamide Peroxide (Whiteness Perfect/FGM Joinville-SC-Brazil) without diet restriction and with use of dye solution; GC: Control group with daily brushing with conventional dentifrice Triple action/Colgate (Brazil) without diet restriction; LW-: Daily brushing with Luminous White Advanced/Colgate (Brazil) toothpaste with diet restriction; LW+: Daily brushing with Luminous White Advanced/ Colgate (Brazil) toothpaste without diet restriction and with the use of dye solution.

Treatment was conducted according to the following protocol: $1^{\text {st }}$ Session: 1) Reading and signing the Term of Consent; 2) Anamnesis; 3) Physical examina- 
tion; 4) Filling out the form of the clinic; 5) Prophylaxis with pumice paste and water; 6) Photographic record; 7) Initial color registration; 8) Delivery of the bleaching product; 10) Treatment guidelines. Further sessions: 1) Evaluation of transoperative sensitivity; 2) Prophylaxis with pumice and water; 3 ) Photographic record; 4) Color registration; 5) Reinforcement of the guidelines.

For the PC- and PC+, a supervised bleaching technique was performed, so the treatment was differentiated. In the first clinical session, in addition to the procedures already described, top and bottom molding with alginate (Jeltrate/Dentsply) and modeling of gypsum stone type III (Diamante) were done to make the custom silicone tray made in the vacuum plastizer. At the second clinical session, the custom tray was delivered with the bleaching agent ( $10 \%$ carbamide peroxide). Guidelines were given for use and care during treatment, which consisted of the use of the tray for eight hours daily during sleep for fifteen days. The other procedures followed the general protocol.

Patients in the GC, LW- and $L W+$ received one of the evaluated toothpaste and performed a minimum of three daily brushings for fifteen days.

Patients in the PC- and LW- were instructed to avoid the consumption of foods and beverages with potential pigmentation, such as coffee, cola-based soft drinks, red wine, chocolate drinks, dye products, heavily pigmented sauces, grapes, beets, strawberries, etc.

However, the patients in the PC+, GC and LW + did not have dietary restrictions. In addition, patients in the PC+ and LW+, in order to ensure contact with dyes, were instructed to perform 3 daily mouthwashes per 30s with $25 \mathrm{ml}$ of grape nectar (Dafruta: Water, apple juice concentrate, sugar, juice grapefruit concentrate; acidulant: Citric acid, flavoring, natural anthocyanin dye; antioxidant: Ascorbic acid, artificial sweetener: Sucralose and acesulfuron/ketotin emulsifier) which was supplied to participants along with dosing cups. Patients were instructed to perform the first mouthwash immediately after removal of the tray and two more during the day, with a minimum of 6 hours between them. In addition, they waited 15 minutes after the mouthwash to brush their teeth [9].

The chromatic modification readings were performed initially (before the start of the study), at the end of the treatment and 15 days after the completion of the bleaching treatment. Measurements were performed with a portable digital spectrophotometer (EasyShade-Vita), on which a silicone positioner was adapted so that the measurement was always taken in the same place as the vestibular crown. The coloring of the middle third of the upper central incisor was taken as a reference, according to the CIELab space of the
Commission Internationale de l'Eclairage. The arithmetic average between the $L^{*} a^{*}$ and $b^{*}$ values of these two teeth were taken into consideration.

To determine the staining differences at different time points of treatment, $\Delta \mathrm{E}$ was calculated by the following formula: $\Delta E^{*}=\left[\Delta L^{*} 2+\Delta a^{*} 2+\Delta b^{*} 2\right] 1 / 2$, where $\Delta \mathrm{L}^{*}=\mathrm{L} 0-\mathrm{L} 1 ; \Delta \mathrm{a}=\mathrm{a} 0-\mathrm{a} 1 ; \Delta \mathrm{b}=\mathrm{b} 0-\mathrm{b} 1$. The $\Delta \mathrm{E}$ was verified at two different times: $\Delta E 1=$ Color at the end of the treatment by the initial color; E2: Color after 15 days by color at the end of treatment.

At each evaluation, the gingival condition was evaluated through clinical examination, where its characteristics were observed as texture and coloration. When any change was observed, the necessary measures were taken for its solution.

In addition to the analysis of treatment efficiency, the patients were asked about the appearance of dental sensitivity during and immediately after the use of whitening products. The measurement of this sensitivity was done through a visual analog scale (VAS), applied through a form filled out by the patient himself.

At the end of the treatment, the patients were evaluated for the degree of satisfaction with the technique and with the results obtained, by filling out a specific form.

The obtained data were tabulated and underwent statistical analysis of the descriptive and inferential type. Absolute and percentage frequencies were analyzed for the categorical variables, and the measures: Average, standard deviation, median and percentiles in the numerical variables. To evaluate the difference between the groups in relation to the categorical variables, Fisher's Exact Test was used (since the condition for Chi-square test use was not verified) and for the comparison between the groups in relation to the numerical variables were used the F (ANOVA) or Kruskal Wallis tests. In the case of a significant difference by the Kruskal-Wallis test, multiple comparisons of mentioned test were used between pairs of groups.

The choice of test $F$ (ANOVA) occurred in situations where normal distribution was verified in each of the groups and the Kruskal-Wallis test in the case of rejection of normality in at least one of the groups. The margin of error used in the decision on the statistical tests was $5 \%$.

The data were typed in the EXCEL worksheet and the program used to obtain the statistical calculations was the SPSS IMB in version 23.

\section{Results}

The researched group ages ranged from 19 to 36-years-old, average of 23-years-old, standard deviation 3.05 years and median of 22.00 . 


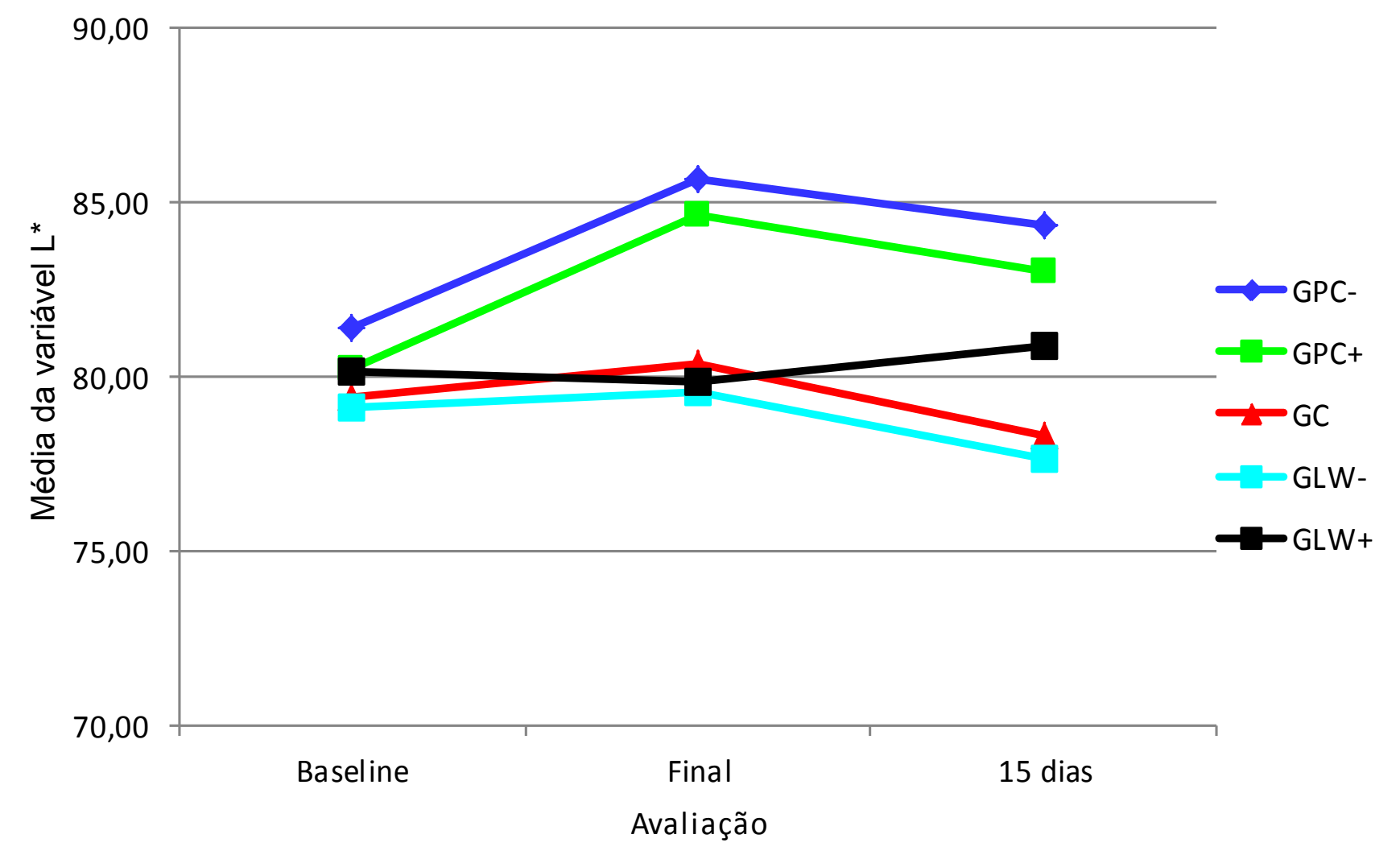

Figure 1: Statistics of the variable " $L$ ".

Table 1: $\Delta \mathrm{E}$ statistics according to group and time of evaluation.

\begin{tabular}{|c|c|c|}
\hline Group & $\begin{array}{l}\Delta \mathrm{E} \text { (Baseline } \mathrm{X} \\
\text { Final) } \\
\text { Average } \pm \mathrm{DP} \\
\text { Median (P25; P75) }\end{array}$ & $\begin{array}{l}\Delta E \text { (Final } X 15 \text { days } \\
\text { after) } \\
\text { Average } \pm \text { DP } \\
\text { Median (P25; P75) }\end{array}$ \\
\hline \multirow[t]{2}{*}{$P C-(n=10)$} & $11.06 \pm 4.66$ & $3.22 \pm 3.08$ \\
\hline & $11.25(8.57 ; 15.29)$ & $3.02(1.30 ; 3.66)$ \\
\hline \multirow[t]{2}{*}{$P C+(n=10)$} & $7.57 \pm 3.93(\mathrm{AC})$ & $4.88 \pm 2.43$ \\
\hline & $6.84(4.94 ; 10.55)$ & $4.44(2.93 ; 5.93)$ \\
\hline \multirow[t]{2}{*}{$\mathrm{GC}(\mathrm{n}=10)$} & $2.90 \pm 2.33^{(\mathrm{B})}$ & $3.32 \pm 2.30$ \\
\hline & $2.26(1.44 ; 4.26)$ & $2.54(1.78 ; 4.57)$ \\
\hline \multirow[t]{2}{*}{ LW- $(n=10)$} & $4.35 \pm 2.29(\mathrm{BC})$ & $3.36 \pm 1.67$ \\
\hline & $4.20(2.20 ; 6.08)$ & $3.54(2.00 ; 4.82)$ \\
\hline \multirow[t]{2}{*}{$L W+(n=10)$} & $3.30 \pm 1.83^{(\mathrm{B})}$ & $4.86 \pm 3.19$ \\
\hline & $3.21(1.58 ; 4.55)$ & $4.27(2.03 ; 7.58)$ \\
\hline Value of $p$ & $\mathrm{P}^{(1)}<0.001^{*}$ & $p^{(2)}=0.234$ \\
\hline
\end{tabular}

(*) Significant difference at 5.0\%.

(1)Through the F test (ANOVA) with Tukey's comparisons.

(2)Through the Kruskal Wallis test.

PS. If all the letters between parentheses are distinct it is verified significant differences between the corresponding groups.

The results related to the characteristics of the sample studied highlight that the majority: Female (60.0\%); had incomplete higher education (88.0\%) and the remaining $12.0 \%$ had higher education. The majority of the sample consisted of singles (98.0\%); born in Recife (72.0\%).
Table 1 presents the results of $\Delta \mathrm{E}$ between baseline and final evaluation, as between final evaluation and 15 days post-treatment. From this chart, we highlight that: Between baseline and final evaluation the average values were higher in GPC- (11.06) and GPC+ (7.57) and ranged from 2.90 to 4.35 in the other groups. The $\Delta \mathrm{E}$ average between the final evaluation and the 15-day re-evaluation were higher in the groups: GPC+ (4.88), followed by the GLW+ (4.86) and ranged from 3.22 to 3.36 in the other groups. For the fixed margin of error $(5 \%)$, a significant difference $(p<0.05)$ was observed between the groups and through the multiple comparison tests, a significant difference was found between: GPCand GC, GLW- and GLW+; and between GPC+ and the $\mathrm{GC}$ and $\mathrm{GLW}+$.

Figure 1 illustrates the speed of bleaching through the behavior of the variable $L^{*}$ during the study. It was observed that the " $\mathrm{L}^{*}$ " averages increased from the baseline to the final evaluation (the averages were positive in the PC-, PC+, GC and LW-) and reduced (the average was negative) in the $\mathrm{LW}+$; the average values of the " $\mathrm{L}$ " "decreased from the final evaluation to 15 days after treatment in the PC-, PC+, GC and LW- (the averages were negative) and increased in the $\mathrm{LW}+$ (positive average). The difference between the groups was recorded in the $\mathrm{L}^{*}$ (final-baseline) variation, being significant among: PC- (average 4.28) and PC+ (average 4.42) compared to GC (average of 0.97) , LW- (average equal to 0.43 ) and LW+ (average equal to-0.30).

Table 2 shows that during treatment there were no 
Table 2: Sensitivity according to the time evaluation and the group.

\begin{tabular}{|c|c|c|c|c|c|c|c|}
\hline \multirow{3}{*}{ Evaluation/group } & \multicolumn{7}{|c|}{ Sensitivity } \\
\hline & \multicolumn{2}{|c|}{ Present } & \multicolumn{2}{|c|}{ Absent } & \multicolumn{2}{|c|}{ Total } & \multirow[t]{2}{*}{ Value of $p$} \\
\hline & $\mathbf{N}$ & $\%$ & $\mathbf{n}$ & $\%$ & $\mathbf{n}$ & $\%$ & \\
\hline During & & & & & & & $\mathrm{p}^{(1)}=0.142$ \\
\hline GPC- & 3 & 30.0 & 7 & 70.0 & 10 & 100.0 & \\
\hline GPC+ & 5 & 50.0 & 5 & 50.0 & 10 & 100.0 & \\
\hline GC & - & - & 10 & 100.0 & 10 & 100.0 & \\
\hline GLW- & 3 & 30.0 & 7 & 70.0 & 10 & 100.0 & \\
\hline GLW+ & 3 & 30.0 & 7 & 70.0 & 10 & 100.0 & \\
\hline All groups & 14 & 28.0 & 36 & 72.0 & 50 & 100.0 & \\
\hline Final & & & & & & & $\mathrm{p}^{(1)}=1.000$ \\
\hline GPC- & - & - & 10 & 100.0 & 10 & 100.0 & \\
\hline GPC+ & 1 & 10.0 & 9 & 90.0 & 10 & 100.0 & \\
\hline GC & - & - & 10 & 100.0 & 10 & 100.0 & \\
\hline GLW- & 1 & 10.0 & 9 & 90.0 & 10 & 100.0 & \\
\hline GLW+ & - & - & 10 & 100.0 & 10 & 100.0 & \\
\hline All groups & 2 & 4.0 & 48 & 96.0 & 50 & 100.0 & \\
\hline
\end{tabular}

(1)Through Fisher's Exact Test.

Table 3: Evaluation of the degree of satisfaction according to the group.

\begin{tabular}{|c|c|c|c|c|c|c|c|c|c|}
\hline \multicolumn{10}{|c|}{ Degree of satisfaction } \\
\hline \multirow[t]{2}{*}{ Group } & \multicolumn{2}{|c|}{ Unsatisfied } & \multicolumn{2}{|c|}{ Indifferent } & \multirow[t]{2}{*}{ Satisfied } & & \multicolumn{2}{|c|}{ Very satisfied } & \multirow[t]{2}{*}{ Value of $p$} \\
\hline & $\mathbf{N}$ & $\%$ & $\mathbf{N}$ & $\%$ & & & $\mathbf{N}$ & $\%$ & \\
\hline GPC- & - & - & - & - & 6 & 60.0 & 4 & 40.0 & $\mathrm{p}^{(1)}<0.001^{*}$ \\
\hline GPC+ & - & - & 2 & 20.0 & 4 & 40.0 & 4 & 40.0 & \\
\hline GC & - & - & 10 & 100.0 & - & - & - & - & \\
\hline GLW- & 4 & 40.0 & 6 & 60.0 & - & - & - & - & \\
\hline GLW+ & - & - & 7 & 70.0 & 3 & 30.0 & - & - & \\
\hline All groups & 4 & 8.0 & 25 & 50.0 & 13 & 26.0 & 8 & 16.0 & \\
\hline
\end{tabular}

${ }^{(*)}$ Significant difference at $5.0 \%$

(1)Through Fisher's Exact Test.

reports of sensitivity in the CG and ranged from 3 to 5 cases among the 10 patients in the other groups, but without significant difference $(p>0.05)$ between them. In the final evaluation, there was only one case of sensitivity report in two groups (GPC+ and GLW-), however with no significant difference between them.

Table 3 shows the degree of satisfaction with the treatment according to the group.

It is emphasized that only in the GPC- and GPC+ there were patients who considered themselves very satisfied with the treatment, each with 4 patients. Considering the amount of satisfied and very satisfied patients, only the GPC-, GPC+ and GLW+ had patients in this condition, being 10 patients in the GPC-, 8 in the GPC+ and 3 in the GLW+; the only patients who considered themselves unsatisfied were allocated to the GLW-, with 4 patients. All 10 patients in the GC considered themselves indifferent to the degree of satisfaction. There was a significant difference between the groups in relation to this variable.

\section{Discussion}

The reason for the present study was the discussion between recent research on tooth whitening, which reduced the influence of contact with some coloring agents during bleaching on the efficacy of this treatment, according to authors such as Rezende, et al. [3], Rezende, Loguercio, Reis [9], Siqueira [10] and Canappele, et al. [11].

However, this is not consensual. There is no evidence of this influence, nor is it clear whether this new design is valid for all modes of bleaching and for all foods/beverages with potential for staining.

Authors such as Decker [12], Cavalcante [5], Téo, et al. [1] and Magalhães [13] believe that the professional should warn patients about the temporary restriction of food intake and coloring drinks during 
Table 4: Bibliographical survey on the influence of contact with food coloring during bleaching.

\begin{tabular}{|c|c|c|c|}
\hline Authors and publication year & Dental bleaching & Type of coloring & Conclusion \\
\hline Decker [12] & $\begin{array}{l}\text { Not mentioned by the } \\
\text { author. }\end{array}$ & $\begin{array}{l}\text { Tea, coffee, açai extract, } \\
\text { grape juice, red wine, coke } \\
\text { and melted chocolate. }\end{array}$ & $\begin{array}{l}\text { Recommendation to avoid food } \\
\text { coloring in office whitening but not } \\
\text { necessary in home whitening. }\end{array}$ \\
\hline Cavalcante [5] & $\begin{array}{l}35 \% \text { of Hydrogen } \\
\text { peroxide. }\end{array}$ & Coffee & $\begin{array}{l}\text { There was interference in the } \\
\text { efficacy of the bleaching being } \\
\text { dose-dependent. }\end{array}$ \\
\hline Rezende, et al. [3] & $\begin{array}{l}16 \% \text { of carbamide } \\
\text { peroxide. }\end{array}$ & $\begin{array}{l}\text { Coffee, coffee with sugar, } \\
\text { black tea, black tea with } \\
\text { sugar, grape juice and grape } \\
\text { juice with sugar. }\end{array}$ & $\begin{array}{l}\text { Bleaching was effective even with } \\
\text { the ingestion of food coloring. }\end{array}$ \\
\hline Rezende, Loguercio, Reis [9] & $\begin{array}{l}16 \% \text { of carbamide } \\
\text { peroxide. }\end{array}$ & Coffee & $\begin{array}{l}\text { There was no influence on } \\
\text { whitening or sensitivity. }\end{array}$ \\
\hline Siqueira [10] & $\begin{array}{l}16 \% \text { of carbamide } \\
\text { peroxide. }\end{array}$ & Coffee & $\begin{array}{l}\text { There is no influence in } \\
\text { effectiveness, longevity and } \\
\text { sensitivity. }\end{array}$ \\
\hline Teo, et al. [1] & $\begin{array}{l}35 \% \text { of hydrogen } \\
\text { peroxide. }\end{array}$ & $\begin{array}{l}\text { Coffee, tea, wine and cola } \\
\text { based soft drinks. }\end{array}$ & $\begin{array}{l}\text { All substances were able to stain } \\
\text { the teeth. }\end{array}$ \\
\hline Caneppele, et al. [11] & $\begin{array}{l}16 \% \text { of carbamide } \\
\text { peroxide. }\end{array}$ & Coffee, wine and coke. & There was no influence. \\
\hline Magalhães [13] & $\begin{array}{l}10 \% \text { of carbamide } \\
\text { peroxide. }\end{array}$ & Açai extract and coffee. & $\begin{array}{l}\text { Teeth undergone to bleaching and } \\
\text { immediately exposed to these food } \\
\text { coloring have a greater potential for } \\
\text { staining. }\end{array}$ \\
\hline
\end{tabular}

Authors who are in favor of restriction of coloring food.

Authors who believe there is no need for food restriction.

and after bleaching, because in the period that the teeth are in contact with the whitening substances, the enamel becomes more porous, with greater roughness superficial and with its microhardness diminished facilitating its pigmentation. However, it is still unsure the precise and convenient time of when introducing back these foods, as well as how often consumption is able to impair bleaching effectiveness. Ideally, the ingestion of coloring substances during and after bleaching would not interfere with the effectiveness of bleaching agents. This restriction is a problem for some patients who make continuous use of certain substances, such as coffee for example. Usual consumers of coffee usually have a high frequency of daily drink intake. Caffeine is a substance that stimulates the central nervous system and can lead to addiction with continued use. A certain apprehension is generated in the habitual consumer when oriented about their restriction during and after the bleaching treatment, since coffee abstinence usually causes discomforts such as headache, nausea, vomiting, drowsiness, among others [14].

Table 4 mentions the authors who studied this influence. Those who believe that there is no need for food restriction with coloring substances during the bleaching treatment are presented in green color, while the authors listed in red affirm that there is a need of this restriction.
In the present study, the results did not point out significant differences between the bleaching result when there was or not daily contact with grape juice both in supervised whitening and in the use of whitening toothpaste, despite the average values of $\Delta E$ were reduced when using this coloring substance ( $\mathrm{Ta}$ ble 1).

On the other hand, a peculiar behavior was observed in the LW+ group, in which the speed of the bleaching effect increased after the removal of the daily contact with the coloring agent, a fact that does not rule out the importance of this interaction.

Both the darkening process and the whitening mechanism are only possible thanks to the relative permeability of dental structures. Therefore, the greater the penetration of the whitening substance into the intimacy of the dental unit, the greater the amount of pigmentation that can be removed, therefore, better aesthetic results are obtained. The whitening substances are subordinated to the biochemical reaction that triggers the rupture of the pigmented molecules that impregnate the dental structures, making them lighter. They produce, consequently, a significant reduction of color intensity, favoring the whitening of the teeth in treatment [15].

It has been discussed that the techniques may promote, in in vitro studies, changes in the superficial micromorphology of the dental tissues that would be re- 
sponsible for alterations in the surface roughness of the whitened ename [5]. This increased enamel roughness associated with bleaching occurs mainly due to the temporary mineral loss of calcium and phosphorus associated with protein change in the superficial enamel, increasing the permeability and at the same time increasing the susceptibility to pigmentation. It is suggested that wine has a greater potential of pigmentation compared to coffee, because it is an acidic substance, has coloration and alcohol in its composition [16].

There is evidence in the literature that discusses that acidic drinks promote greater dental browning due to the low $\mathrm{pH}$ value. Talking about the grape juice, used as a coloring agent in this study, it presented a $\mathrm{pH}$ of 2 , but did not have a significant influence on the result. Comparative studies between dyestuffs with different $\mathrm{pH}$ are required to observe this influence.

Besides $\mathrm{pH}$, the staining of the teeth may be related to the presence of sugar in the coloring drinks. Guler, et al. observed that the presence of sugar in coffee and tea enhanced the staining in resins used to make temporary teeth. Although the dental structure presents distinct characteristics of these resins, the presence of sugar, which is often seen in beverages/food coloring, could corroborate for the extrinsic staining of the teeth [17]. However, Rezende, et al. concluded that tooth whitening was effective even in the presence of food coloring during the bleaching treatment with $16 \% \mathrm{PC}$, regardless of the presence of sugar [3].

Another point to consider is that most studies are performed in the laboratory, where the dental structure is undergone to a more critical and aggressive situation than in the oral environment. It cannot be presumed that a simple application of a bleaching agent on specimens and the use of artificial saliva or other remineralizing solutions are simulating intraoral conditions [5].

Both the work of Canapelle [11] and that of Rezende [3] emphasized the saline remineralization power acting as a barrier preventing the penetration of pigments on the dental surface.

Remineralization may be expected in vivo, due to the following factors: Salivary flow, saliva buffering ability, oral hygiene, and use of topical fluorides that may enhance the remineralization of bleached enamel and dentin $[18,19]$.

Another finding of great relevance in this research reinforces the evidence that domestic bleaching products such as dentifrices do not produce a real bleaching effect. Table 1 and Figure 1 show that the groups of patients who used dental bleaching creams with and without diet restriction behave practically the same to the control group, and this one presented more satisfactory results even though there were not any bleaching substances neither abrasives. Probably, the reinforcement given to patients in maintain- ing good hygiene even with the use of conventional toothpaste has contributed to an effective removal of extrinsic stains from the teeth, reducing the degree of pigmentation in the evaluations.

One of the possibilities for the group that used the whitening toothpaste and showed darkening is the fact that these dentifrices have abrasives, which maximize the removal of only superficial extrinsic stains, but also cause excessive wear on the surface of the enamel, leaving its lower thickness, contributing to the more yellowing of the dentine. According to Bueno, et al. this abrasiveness can generate an increase in the porosity of the tissues, which would predispose the tooth to future stains [20].

This reinforces the concern of the academic community about patient's free access to these products, since they are aware of their great abrasive potential. It is worth remembering that Resolution RDC $n^{\circ} 6$ of 2015 of ANVISA refers to the bleaching agents and it is advised that these be marketed directly to a legally qualified professional and legal entities that provide dental services by submitting an application in a competent Professional Council, however, the non-whitening toothpaste does not are included in this Resolution. In this case, there is no obstacle on the part of the population regarding the acquisition of these dental creams in supermarkets and drugstores.

It should be pointed out that patients with clinical phenomena such as bruxism, brushing habits with excessive force or exposure of dentin can be hampered by the continuous use of dental creams with abrasive potential. Because the treatment is totally devoid of professional accompaniment, the non-efficacy of bleaching stimulates the continuous and uninterrupted use of bleaching dental creams aggravating the problem over time.

This dissatisfaction was characterized in this research in the groups that used bleaching dentifrices considering that the majority of the patients were indifferent or unsatisfied with the treatment. On the other hand, the groups that used bleaching with $10 \%$ Carbamide Peroxide, the degree of satisfaction was higher.

With the current appreciation of dental aesthetics and the importance of the whitening technique, even as a precursor to most previous rehabilitations, accurate knowledge about the aspects that guide the tooth coloration and its alterations shows a great importance in self-esteem. It is worth emphasizing the importance of professional follow-up in this treatment to inform the patient of his limitations, thus avoiding future frustrations [21-23].

It is possible to realize, therefore, that there is a great divergence of the researchers/authors regarding the effect of the exposure of the bleached enamel to coloring substances that can interfere in the effective- 
ness of the bleaching treatment and the stability of the results over time.

\section{Conclusions}

1) Among the bleaching strategies analyzed, only the supervised technique with the use of $10 \%$ Carbamide Peroxide obtained a satisfactory bleaching effect; 2) The contact with the coloring substance did not significantly influence the bleaching effectiveness of supervised and domestic techniques; 3) Patients who used Carbamide Peroxide had a higher degree of satisfaction with the treatment; 4) There was no difference between the groups about the reports of sensitivity.

\section{References}

1. Téo TB, Takahashi MK, Gonzaga CC, Maria da GKL (2010) Avaliação, após clareamento, da alteração de cor de dentes bovinos imersos em soluções com elevado potencial de pigmentação. Revista Sul Brasileira de Odontologia 7: 401-405.

2. Farinelli MV, Paulo PR, Nogueira RD, Geraldo-Martins VR (2013) Efeitos do clareamento dental em restaurações de Resina Composta. Cient Ciénc Biol Saúde 15: 153-159.

3. Rezende M, Cerqueira LL, Loguercio AD, Reis A, Kossatz $S$ (2014) Dyes with and without sugar versus effectiveness of dental bleaching-an ex vivo study. Rev Odontol Bras Central 23: 146-150.

4. Mello DCCL (2014) Avaliação in vitro do poder clareador dos cremes dentais sobre a estrutura dental. UEPB.

5. Cavalcante DHB (2015) Influência da frequência de ingestão de café na cor dos dentes durante o clareamento com peróxido de hidrogênio a 35\%. Rio Grande do Norte. Universidade Federal do Rio Grande do Norte.

6. Marson FC, Sensi LG, Araújo FO, Sylvio Monteiro Junior, Élito Araújo (2005) Avaliação clínica do clareamento dental pela técnica caseira. R Dental Press Estét 2: 84-90.

7. Matta MC, Durães I, Araújo RPC, Paula MMC (2015) Efeito de dentifrícios clareadores na rugosidade superficial de resina composta nanoparticulada. Revista de Ciências Médicas e Biológicas 14: 400-405.

8. Mariz ALA, Fernandes JV, Guimarães RP, Silva CHV (2007) Conhecendo os cremes dentais clareadores. Dental Science 1: 93-97.

9. Rezende M, Loguercio AD, Reis A, Kossatz S (2013) Clinical effects of exposure to coffee during at-home vital bleaching. Oper Dent 38: 229-236.

10. Siqueira MFR (2012) Avalianção clínica da influência do café na efetividade do clareamento dental. Universidade Estadual de Ponta Grossa.
11. Canappele TMF, Souza AC, Valera MC, Clovis Pagani (2009) Influência da embebição dental em substâncias com corantes na eficácia do clareamento dental com peróxido de carbamida a $16 \%$. Arquivos em Odontologia 45: 171177.

12. Decker FW (2017) A dieta corante interfere no resultado do clareamento dental? Uma revisão sistemática. UFSC.

13. Magalhães JG (2007) Avaliação do manchamento causado por pigmentos provenientes de bebidas em dentes clareados. Universidade Estadual Paulista.

14. Mendes FR, Mattei R, Tabach R, Etiana Rodrigues, Elisaldo LAC (2005) Avaliação de um extrato de café em modelos animais de depressão e síndrome de abstinência à morfina. Arquivos brasileiros de Fitomedicina Cientifica 2: 56-66.

15. Araújo DB, Campos EJ, Silva LR, Roberto Paulo CA (2009) Lesãoes do esmalte dental relacionadas aos dentifrícios clareadores. R Ci med Boil Salvador 8: 171-181.

16. Santos I, Santana LKC, Giulliana PS (2017) Clareamento dental, uma análise da influência da injestão de alimentos com potencial de pigmentação durante o tratamento: Revisão de literatura. Universidade Tiradentes.

17. Guler AU, Yilmaz F, Kulunk T, Guler E, Kurt S (2005) Effects of different drinks on stainability of resin composite provisional restorative materials. J Prosthet Dent 94: 118124.

18. Ana Paula CC, João Thomaz LA, Fábio BS, Renata PG (2005) Avaliação da permeabilidade do esmalte exposto a diferentes concentrações de peróxido de hidrogênio e peróxido de carbamida. Odontologia Clinico-Cienficica 4: 207-211.

19. Araújo RM, Torres CRG, Araújo MAM (2006) Influência dos agentes clareadores e um refrigerante a base de cola na microdureza do esmalte dental e a ação da saliva na superfície tratada. Revista Odonto Ciência 21: 118-124.

20. Bueno FG, Lopes LG, Souza JB, Lourenço CS, Rodrigo BF (2011) Influência de diferentes dentifrícios clareadores na cor dental e topografia superficial após ciclos de escovação. Faculdade de Odontologia.

21. Barbosa DC, De'stefani TP, Ceretta LB, Simões PW, D'altoé LF (2015) Comparative study of tooth whitening techniques in office and supervised at home in vital teeth: $A$ literature review. Rev Odontol Univ Cid São Paulo 27: 244252.

22. Altman DG (1991) Practical statistics for medical research. Chapman and Hall, Great Britain, 611.

23. Conover WJ (1980) Practical nonparametric statistics. John Wiley \& Sons, Texas, 495. 